Discussion Paper No. 05-01

\title{
The Costs of
}

\section{Supervisory Fragmentation in Europe}

Martin Schüler and Friedrich Heinemann

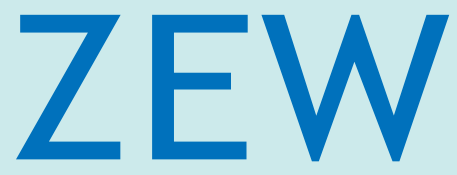

Zentrum für Europäische Wirtschaftsforschung $\mathrm{GmbH}$

Centre for European

Economic Research 
Discussion Paper No. 05-01

\title{
The Costs of Supervisory Fragmentation in Europe
}

\author{
Martin Schüler and Friedrich Heinemann
}

Download this ZEW Discussion Paper from our ftp server:

ftp://ftp.zew.de/pub/zew-docs/dp/dp0501.pdf

Die Discussion Papers dienen einer möglichst schnellen Verbreitung von neueren Forschungsarbeiten des ZEW. Die Beiträge liegen in alleiniger Verantwortung der Autoren und stellen nicht notwendigerweise die Meinung des ZEW dar.

Discussion Papers are intended to make results of ZEW research promptly available to other economists in order to encourage discussion and suggestions for revisions. The authors are solely responsible for the contents which do not necessarily represent the opinion of the ZEW. 


\section{Non-Technical Summary}

Financial markets in Europe become more and more integrated. The persisting fragmentation of financial supervision, however, constitutes a lasting obstacle to integration. Financial services providers operating in different European countries have to deal with a multitude of supervisory agencies and regulations. The outcome of this is additional costs that may, for instance, prevent firms from entering foreign markets, and hence hamper financial integration.

Overall the costs resulting from supervisory fragmentation in Europe are manifold and complex. They range from the cost burden within financial companies, such as costs due to multiple reporting, up to general macroeconomic costs as a result of supervision related obstacles to market development and integration. The aim of this paper is to assess the costs that result from national fragmentation of financial supervisory systems in the EU. These costs are related to the potential savings from a reform of the supervisory framework towards a more cost-efficient system.

To this end we employ a two step procedure. Firstly, a supervisory cost function is estimated for a large country cross-section. Due to data availability we focus the analysis on the institutional costs of banking supervision. Supervisory cost is explained by 'supervisory output' as well as several control variables. Thereby, the extent of economies of scale can be quantified. Secondly, we use these estimation results to predict the supervisory cost in a cost-efficient European supervisory system assuming that the economies of scale could be realised for the whole of the EU. The dimension of potential cost savings is then calculated by relating these predictions to the sum of the actual supervisory costs in the current national based framework.

The results clearly indicate that there exists increasing economies of scale in banking supervision. An increase in supervisory output (measured by the size of the banking market) by one percent causes institutional supervisory cost (measured by supervisory staff) to rise by only some 0.5 percent. Based on these estimation results we predict institutional cost saving of around 15 percent in a plausible simulation scenario representing a cost-efficient European supervisory framework. 


\title{
The Costs of Supervisory Fragmentation in Europe
}

\author{
Martin Schüler and Friedrich Heinemann*
}

Centre for European Economic Research (ZEW), Mannheim

January 2005

\begin{abstract}
Financial markets in Europe become more and more integrated. The persisting fragmentation of financial supervision, however, constitutes a lasting obstacle to integration. The aim of this paper is to assess these costs of supervisory fragmentation. We find clear evidence for the existence of economies of scale in banking supervision. An increase in supervisory output by one percent causes institutional supervisory cost to rise by only some 0.5 percent. Based on these estimation results we predict institutional cost saving of around 15 percent in a plausible simulation scenario representing a cost-efficient European supervisory framework.
\end{abstract}

JEL-Classification: G28

Keywords: financial supervision, costs, economies of scale

* Corresponding author. Centre for European Economic Research (ZEW) P.O. Box 103443, D-68034 Mannheim, Germany, Phone: +49/621/1235-149, Fax: +49/621/1235-223, E-mail: heinemann@zew.de. 


\section{Introduction}

Financial markets in Europe become more and more integrated. This holds true particularly with respect to wholesale financial markets. However, there still exist manifold obstacles impeding the development of a single retail financial market in Europe (European Commission, 2002; Heinemann and Jopp, 2002; Gual, 2004). One of these obstacles is the fragmentation of financial supervision and regulation in the European Union (EU). ${ }^{1}$ Financial services providers operating in different European countries have to deal with a multitude of supervisory agencies and regulations. The outcome of this is additional costs that may, for instance, prevent firms from entering foreign markets, and hence hamper financial integration.

Overall the costs resulting from supervisory fragmentation in Europe are manifold and complex. They range from the cost burden within financial companies, such as costs due to multiple reporting, up to general macroeconomic costs as a result of supervision related obstacles to market development and integration. The aim of this paper is to assess the costs that result from national fragmentation of financial supervisory systems in the EU. These costs are related to the potential savings from a reform of the supervisory framework towards a more cost-efficient system.

To this end we employ a two step procedure. Firstly, a supervisory cost function is estimated for a large country cross-section. Due to data availability we focus the analysis on the institutional costs of banking supervision. Supervisory cost is explained by 'supervisory output' as well as several control variables. Thereby, the extent of economies of scale can be quantified. Secondly, we use these estimation results to predict the supervisory cost in a cost-efficient European supervisory system assuming that the economies of scale could be realised for the whole of the EU. The dimension of potential cost savings is then calculated by relating these predictions to the sum of the actual supervisory costs in the current national based framework.

The results clearly indicate that there exists increasing economies of scale in banking supervision. An increase in supervisory output (measured by the size of the banking market) by one percent causes institutional supervisory cost (measured by supervisory staff) to rise by only some 0.5 percent. Based on these estimation results we predict institutional cost saving of around 15 percent in a

${ }^{1}$ The notions supervision and regulation are used interchangeable. Note, moreover, that we do not differentiate between the EU and Europe. The notion EU refers to the EU 15, i.e. not the enlarged EU. 
plausible simulation scenario representing a cost-efficient European supervisory framework.

The paper is organised as follows. Section 2.1 gives a systematisation of the costs of supervision in general. Section 2.2 discusses the different costs that are due to fragmentation of financial supervision in the EU. Section 3 tries to quantify the excessive institutional costs. After describing the methodology and data (Section 3.1), the supervisory cost function is estimated (Section 3.2). Based on the estimations the potential costs savings are predicted in Section 3.3. Finally, Section 4 concludes.

\section{Costs of Financial Regulation}

\subsection{A Systematisation}

The costs of financial supervision can be divided into three classes of costs (Goodhart et al., 1998; Alfon and Andrews, 1999; Briault, 2003):

1. Institutional costs of running supervisory agencies which arise in the state sector.

2. Costs of compliance that can be attributed to the regulated firms, i.e. the producers.

3. Structural or distortion costs which arise in the (financial) market.

For an illustration of the costs of financial regulation see Figure 1.

- insert Figure 1 about here -

Institutional costs are the costs which emerge by running regulatory authorities. These costs are usually borne by the regulated industry through fees which often cover the supervisory authority's full budget. In this case they can be regarded as the financial industry's direct regulatory costs which are part of the industry's compliance costs.

The costs of compliance are the costs which are imposed on regulated firms, namely the producers, through regulation. The producer's costs of regulation consist of operating and opportunity costs (Elliehausen, 1998).

Operating costs comprise all cost factors which arise from the active compliance with regulatory requirements (e.g., disclosure and reporting requirements) in addition to the fees (direct costs) that are used to finance the supervisory agencies. These costs comprise all expenses that are generated in this context: 
employee time, material, and equipment as well as managerial effort and training must be devoted to implementing required actions and ensuring compliance with the regulation. This includes in particular labour costs, information technology costs, and costs for equipment, supplies and premises. In addition, particularly when implementing new regulation - for example when entering a new (foreign) market - external legal assistance and consultancy is required.

Opportunity costs arise for the financial firm when regulation prevents it from engaging in profitable activities. Regulation may, for instance, discourage or even prevent firms from expanding their activities to other (e.g., foreign) markets. Thereby, a firm is not allowed to take advantage of profitable business outside its local area and, in addition, is made vulnerable to downturns in local business conditions. Another opportunity cost is the interest foregone due to capital requirements. The firms' opportunity costs constitute a part of the structural costs.

Structural costs arise from the way in which regulation effects markets. Regulation may change the nature of markets, may prevent or discourage firms from entering or using markets, and may constitute new markets that would not exist in the absence of regulation. Thus, regulation may have a significant effect on the nature and availability of financial products. In particular, structural costs include, e.g., possible impairment of competition, stifling of innovation, regulatory capture, and regulatory escalation (regulation becomes excessively burdensome over time). This type of cost, though extremely hard to measure precisely, is of paramount importance in the context of the imperfect single financial market which has to be regarded as one of the responsible factors for the poor European growth performance.

\subsection{The Costs of Fragmentation of Supervision in Europe}

The focus of this paper is not on the overall costs of financial regulation. Instead, the leading question is the following: What are the costs due to the national fragmentation of supervisory systems in the EU? To put it differently, what is the cost saving potential from a reform of the European supervisory system towards a more efficient framework?

Note at this point that our exercise does not necessarily presuppose that Europe would need a centralised supervisory system. It might well be the case that improved coordination and intelligent concepts such as lead supervision approaches could be able to reap substantial economies of scale even within a decentralised system with continuing strong responsibilities of the national agencies. Hence, when we talk in the following of a cost-efficient European supervisory system we leave it open how centralised this system has to be. 
The systematisation of supervisory costs given in the previous section is helpful to identify the different types of excess costs under the status quo.

Firstly, there are additional institutional costs due to the fact that instead of having a cost-efficient European supervisory system there are 15 (and even more since sometimes there are multiple supervisors in one country) national financial supervisors with sub-optimal coordination. Cost savings in this context rely on the assumption of economies of scale in supervision, i.e. that an increase in the 'supervisory output' leads to an increase in the associated (institutional) costs of supervision by a factor of less than one.

These additional institutional costs constitute in turn additional direct compliance costs to the financial firms as firms fund supervisory budgets through fees.

Secondly, supervisory fragmentation leads to a variety of other additional compliance costs to financial institutions. These arise particularly due to multiple reporting requirements. In the EU, at present, the financial reporting requirements are not harmonised or co-ordinated. Thus, the multiplicity of underlying regulatory requirements across countries lead to fragmented reporting systems at the firm level which restrict the institutions' ability to achieve efficiency in reporting (Forum Group, 2002). Reporting requirements differ with respect to, e.g., the definitions and classifications of the requested reporting items; the frequency and dates of the requested time-tables; the required level of detail; and the technical formats. This fragmentation leads to additional indirect costs in the form of, e.g., additional workforce, IT, and other equipment.

Finally, multiple reporting requirements lead to additional opportunity costs to the firms. Differences in regulatory regimes among EU countries constitute a barrier to entry of new foreign markets (Heinemann and Jopp, 2002; Forum Group, 2002). Consequently, firms are prevented from engaging in profitable activities. At a macroeconomic level this constitutes additional structural costs of financial supervision since supervisory fragmentation exhibits a significant obstacle to financial market integration.

Assessing the costs of fragmentation of supervisory regimes in the EU in a quantitative manner is difficult - probably even more difficult than quantifying the overall costs of regulation. In particular, it is hard to reasonably assess the structural costs of regulation since this requires knowledge about the state of markets that would occur in the absence of regulation. Quantifying appropriately the compliance costs to the firms would require detailed surveys and interviews. These approaches face the difficulty that for a large financial services provider it 
is hardly possible even to identify all regulatory costs, not to mention separation of the costs that are due to multiplicity of the regulatory requirements.

Due to these problems, and hence data availability with respect to the structural and the compliance costs, we focus on the institutional costs of supervision. Although, data on the institutional costs is also scarce, there is some crosscountry data available on budget and staff size for banking supervision. Thus, the focus of the quantitative analysis is on banking supervision only.

Employing a large cross-country database we try to estimate economies of scale in banking supervisory activity. Based on these estimations we try to assess the excessive institutional costs that are due to a fragmentation of supervision in the EU.

\section{Quantification of Excessive Institutional Costs}

\subsection{Methodology and Data}

The aim of this paper is to assess the excess institutional costs arising from the fragmentation of banking supervision in the EU. To this end, the analysis proceeds in two steps:

Firstly, a supervisory cost function is estimated for a large country cross-section. The cost of banking supervision is explained by 'supervisory output' as well as several control variables. Thereby, the extent of the economies of scale can be quantified. $^{2}$

Secondly, based on the estimation results we identify the potential cost savings for the EU assuming that the economies of scale could be realised for the whole of the EU and that we would have a cost-efficient European supervisory system. This is done by comparing the sum of the actual costs of running supervisory agencies in the present national based framework with the counterfactual of having a cost-efficient European supervisory framework. This counterfactual is obtained by inserting the values of the explanatory variables for the whole of the EU in the estimated supervisory cost function.

${ }^{2}$ Goodhart et al. (2002) find evidence for economies of scale in supervision. They, however, focus on the staffing and expertise supervisory institutions employ in an attempt to shed more light on the question of which structure may do better. Employing a larger crosscountry dataset, we focus on the determinants of staff from the perspective of the costs of supervision. 
With regard to the first step, we estimate a cost function of the Cobb-Douglas type. The cost of supervision is assumed to depend on supervisory output in a non-linear way which allows for economies of scale. By estimating this nonlinear cost function in logarithms we can apply ordinary least squares estimation methods. Furthermore, the estimated coefficients can be interpreted as elasticities. In addition to the supervisory output we include several explanatory variables to control for market characteristics, supervisory structure, as well as the macro-economy. Thus, the following model is estimated:

$$
\ln (\text { cost of supervision })=\alpha+\beta \ln (\text { supervisory output })+\gamma \ln (\text { control variables })+\varepsilon \text {. }
$$

We use the following variables as proxies for the cost of supervision and supervisory output. For a detailed description of the variables as well as the data source see Table A1 in the Appendix. Summary statistics are shown in Table A2; and Table A3 displays the countries included in the sample.

Our database comprises two variables representing the cost of banking supervision as the dependent variable: Total budget for banking supervision (BUDGET) and total number of professional bank supervisors (STAFF). Supervisory budget is a direct measure for the cost of supervision. When using STAFF as a proxy for supervisory cost we assume that labour cost is the only cost factor and that it is directly proportional to the rest of the costs. This corresponds to the assumption that the underlying production function has only labour as an input factor which is necessary since data on capital is not available. However, this seems to be a reasonable assumption.

As proxies for the supervisory output we include bank assets (ASSETS), deposits (DEPOSITS), claims (CLAIMS), and the number of banks (BANKS). One would expect the coefficient associated with supervisory output to be positive and less than one, indicating that an increase in the size of the banking market of one percent leads to a rise in supervisory cost by only less than one (increasing economies of scale).

In addition, we include three classes of control variables:

\section{Banking market structure:}

We include control variables characterising the banking market. In particular one would expect supervisory cost to be lower in more concentrated and homogeneous banking markets. Thus, we include concentration measures such as the percentage of assets (CONCA) and deposits (CONCD) accounted for by the largest banks, respectively; and the interest rate spread, i.e. the lending minus the deposit rate (DRATES). 
Regarding the homogeneity, we construct the variable HOMOGEN. This variable is the sum of the squared percentage of banking system's assets in banks that are $50 \%$ or more government owned, foreign owned, and privately domestic owned, respectively. By definition this variable ranges from 0.33 to $1 ; 1$ indicating the highest degree of homogeneity. This variable is also very important for the following simulation in order to assess the potential costs savings with a more centralised European supervisory system. The European banking market as a whole is of course far more heterogeneous than any national banking market.

Moreover, we include non-performing loans (NPL) as an indication for the soundness of the banking market. A more fragile banking market is expected to be more costly to supervise. However, there may be a problem of causality since the quality of supervision, and hence also the supervisory cost, should have an effect on the non-performing loans ratio.

Features of the supervisory system:

We also include control variables characterising the supervisory system. Supervisory cost may depend on the number of supervisory authorities. Therefore, we include a dummy variable taking a value of one if there exists more than one bank supervisory authority (MULTI). Moreover, dummy variables are included that indicate whether the central bank is involved in bank supervision (CB), and whether there exists explicit deposit insurance (DI).

\section{$\underline{\text { Other control variables: }}$}

Finally we include variables representing the development of the economy and regional contexts, namely GDP per capita (GDPCAP) and regional dummies for OECD, EU15, EWU, and EU25 countries.

Our database comprises 113 countries with data for the years 1999 and 2002 giving us a maximum of 226 observations.

We estimate a pooled linear regression model of the general form. In other words, we assume that the intercept, the slope coefficients, and the error variances are homogeneous, i.e. constant across countries and time. This is reasonable because of the following: First, we control explicitly for a multitude of factors measuring heterogeneity. Moreover, since our data set comprises only two years and this even not for all countries, estimation of a fixed effects model as well as a random effects model would leave us with very few degrees of freedom. With respect to structural changes over time, we apply a Chow test to several different model specifications. The result is that coefficients of the model estimated with only 2002 data do not significantly differ to the coefficients of the model estimated with 1999 data. 


\subsection{Estimation of the Cost Function}

We estimate several specifications with either the number of bank supervisors (STAFF) or the supervisory budget (BUDGET) as the proxy for supervisory cost, i.e. the dependant variable.

\section{Estimations with STAFF as the supervisory cost variable}

Tables 1, 2, 3, and 4 report the results for the regressions with STAFF as the dependant variable and ASSETS, DEPOSITS, CLAIMS, and BANKS as the supervisory output variable, respectively. In addition to the supervisory output variable we included in all regressions (i) the variable HOMOGEN; (ii) a measure of the concentration of the banking market (CONCA in combination with ASSETS, CLAIMS, and BANKS; CONCD in combination with DEPOSITS, CLAIMS, and BANKS; and DRATES in combination with all supervisory output variables); (iii) GDP per capita (GDPCAP); and (iv) a constant.

\section{- insert Tables 1, 2, and 3 about here -}

The regressions with ASSETS, DEPOSITS, and CLAIMS as the proxy for supervisory output give very similar results. The coefficient associated with supervisory output is significantly positive and less than one in all specifications. In the case of ASSETS the coefficient takes values of around 0.50/0.51; in the case of DEPOSITS of around 0.49; and in the case of CLAIMS between 0.42 and 0.46 . This, indicates that a one percent rise in supervisory output increases supervisory staff by some 0.5 percent. In other words there are increasing economies of scale, which promise cost savings when moving towards a more centralised supervisory framework in the EU.

The constructed homogeneity variable is, as expected, significantly negative. The more homogeneous the banking market, the lower is the number of bank supervisors. To put it differently, more heterogeneous banking markets are more costly to supervise.

The coefficient associated with the concentration in the banking sector (CONCA and (ONCD) is in all specifications negative and in most of the cases significant. In particular in the regressions with DEPOSITS and CLAIMS as the supervisory output variables the concentration measures are highly significant. These results confirm the hypothesis that higher concentrated banking markets require fewer supervisory staff since they are less costly to supervise.

Using the interest rate spread (DRATES) as an indirect measure of the concentration in the banking sector the coefficient turns out to be not significant (equations (7), (8), and (9)). The insignificant coefficient is positive which is in 
contrast to expectations, since a large interest rate spread should indicate higher concentration.

The non-performing loan ratio as a control variable for the soundness of the banking system does not significantly effect supervisory staff size in most regressions. The coefficient is significantly positive only in a few specifications (equation (6) in Table 1 and 2, respectively). A higher non-performing loans ratio is associated with higher supervisory staff which means that a more fragile banking system causes higher supervisory cost. However, there may be a problem of causality since supervisory staff may influence non-performing loans. We therefore exclude NPL from most of the regressions, which is also reasonable since the coefficient is mostly insignificant anyway.

We include three variables controlling for the structure of the supervisory system: a dummy variable indicating whether there are multiple bank supervisors (MULTI), the central bank is involved in banking supervision (CB), and there is explicit deposit insurance (DI), respectively. MULTI is statistically not significant. Also the coefficient doesn't even take the expected sign. It usually is negative, indicating that countries with more than one bank supervisory authority have fewer bank supervisors. The dummy variable CB is significantly positive in some specifications. Countries where the central bank is involved in bank supervision have ceteris paribus higher supervisory staff. ${ }^{3}$ Moreover, the dummy DI is positive and highly significant in all regressions. The existence of explicit deposit insurance is associated with higher supervisory staff. This is reasonable since deposit insurance may cause moral hazard behaviour of banks resulting in higher supervisory cost.

As a macroeconomic control variable we include GDP per capita which turns out to be highly significant with a negative sign. Richer countries employ ceteris paribus fewer staff to supervise the banking system. One reason for that may be lower efficiency and cheaper labour costs in poorer countries.

In addition, we include several regional dummies indicating whether a country belongs to the OECD, the EU15, the EWU, and the EU25, respectively. None of these dummy variables turns out to be significant. The reason for that may be that we control for country differences by including GDP per capita. The results of these regressions are therefore not reported.

${ }^{3}$ Goodhart et al. (2002) find a similar result and wonder whether this could be due to a stronger funding position of Central Banks. 
Basically the same results are found when using the number of banks (BANKS) as a proxy for supervisory output instead of ASSETS, DEPOSITS, and CLAIMS (see Table 4).

$$
\text { - insert Table } 4 \text { about here - }
$$

Most importantly the economies of scale hypothesis is supported. Moreover, the concentration measures (in particular CONCD) are significantly negative; and also the deposit insurance dummy is highly significant with a positive sign. However, HOMOGEN and GDPCAP are mostly not significant, although taking the expected sign.

Overall, the R-squares of these regressions are relatively low (between 0.55 and 0.57) as compared to the regressions with ASSETS, DEPOSITS, and CLAIMS as the output variable where R-squares usually range between 0.65 and 0.71 .

\section{Estimations with BUDGET as the supervisory cost variable}

In addition to the regressions with STAFF as the proxy for supervisory cost we run several specifications using the total budget of supervisory authorities (BUDGET) as the dependant variable.

$$
\text { - insert Table } 5 \text { about here - }
$$

With respect to our main explanatory variable, the supervisory output, the same results emerge: an increase in supervisory output by one percent results in an increase in supervisory budget by less than one percent. In other words, the economies of scale hypothesis is endorsed.

The concentration variables are mostly significantly negative, confirming that a more concentrated banking market causes lower supervisory cost. As opposed to the STAFF-regressions DRATES, the interest rates spread, is significant and positive. This, doesn't go with DRATES as a proxy for the banking market concentration, since one would expect a negative sign (higher interest rate spread indicating higher concentration). However, DRATES may rather measure efficiency of the banking market. In this case a negative sign would indicate that more efficient banking markets are associated with lower supervisory cost.

Most of the other control variables, in particular HOMOGEN and GDPCAP are not significant and/or do not have the expected sign.

Due to lack of data for bank supervisory budgets the number of observations is relatively low (between 80 and 90). Besides, the regressions exhibit relatively 
low R-squares. Therefore, we rely in the next step of the analysis on the estimations with STAFF as the supervisory cost variable.

\subsection{Prediction of Potential Cost Savings}

We use the regression results from the preceding section to identify the potential cost savings for the EU from a move towards a cost-efficient supervisory system. To this end, we assume that we would have a supervisory system where all economies of scale would be realised for the whole of the EU.

By inserting the values of the explanatory variables for the whole of the EU in the estimated cost function, we obtain predictions. Using supervisory staff as the proxy for the supervisory cost, we obtain a prediction of the staff size that would be necessary to supervise the European banking market in a cost-efficient European supervisory system. The potential staff saving is then calculated by subtracting this predicted EU staff size from the actual EU staff level.

Based on overall fit and plausibility we use the following estimation equations for the predictions: With ASSETS as the supervisory output variable we use specifications (3) and (4) from Table 1; with DEPOSITS specifications (3) and (4) from Table 2; and with CLAIMS specifications (2), (3), (5), and (6) from Table 3. We do not use estimation results with BANKS as the supervisory output variable for making predictions.

With respect to EU values of the explanatory variables the following applies (see Table A4 in the Appendix for summary statistics): We use 2002 data. For ASSETS, DEPOSITS, and CLAIMS we use the sum of the national values; for GDPCAP the weighted EU average. Moreover, we assume that at the European level the ECB would not be involved in banking supervision (CB takes the value 0 ); and that - as in all EU countries - there would be explicit deposit insurance (DI takes the value 1).

No data for the whole EU is available for the variables HOMOGEN, CONCA and CONCD. Taking (weighted) averages would be misleading since the EU banking market as a whole is most likely more heterogeneous and less concentrated than any single national market. Therefore, we differentiate scenarios based on different assumptions with respect to the homogeneity and the concentration of the EU banking market. We assume that HOMOGEN takes the values 0.45 (the weighted EU average), 0.33, and 0.1, respectively. Recall that lower values indicate a more heterogeneous market. According to the construction of this variable (cf. Table A1) the lowest possible value would be 0.33 . However, it is reasonable to assume a lower value for the EU banking market as a whole since differences between national markets increase heterogeneity at the EU level. 
Moreover, we assume that the concentration variable CONCA/CONCD takes values of 40.69/38.19 (the weighted EU average), 20, and 10, respectively. These assumptions result in nine different scenarios for the prediction of the EU staff size.

Table 6 shows the predicted staff size and the percentage staff saving (in parentheses) for these nine scenarios. Each column in the table represents one of the estimation equations selected for making predictions. The first two with ASSETS as the supervisory output variable; the second two with DEPOSITS; and the final four with CLAIMS. Each row in the table represents one of the nine scenarios.

\section{- insert Table 6 about here -}

Not surprisingly, the predicted EU staff size depends heavily on the assumptions regarding the homogeneity and the concentration of the EU banking market. The more heterogeneous and the less concentrated the banking market, the higher predicted staff size, and thus the lower potential staff savings.

Assuming that the variables HOMOGEN and CONCA/COND take the average value of the EU countries (scenario 1), results in predicted EU staff size that lies between 657 and 917 persons, or staff savings of between 75 and 83 percent. Of course these numbers are anything but realistic. The reason for that are the assumptions that the EU banking market as a whole exhibits the same level of homogeneity and concentration as the average national EU market. Clearly, this is not reasonable.

More reasonable is to assume lower levels of homogeneity and concentration which also lowers the potential staff savings. For instance, the scenario 7 assumes HOMOGEN to be 0.1 and CONCA/CONC to be 20. National differences will cause the EU banking market to be always more heterogeneous than any national banking market and, therefore, make its supervision a rather complex undertaking. Thus, a value for the variable HOMOGEN significantly lower than the minimum of 0.44 in the EU sample is justified. With respect to concentration, it seems plausible that a future EU banking market will see some truly European (or even global) players, which account for a significant share of the market. Thus, assuming a value of 20 for the variable CONCA/CONCD, i.e. a market share of 20 percent of the top 5 banks, seems to be reasonable (at least in the foreseeable future). For comparison, in Germany (the least concentrated market in the EU) CONCA is 20 and CONCD is 21.

For instance, in the plausible scenario 7 predicted EU staff size lies between 2410 and 3303 depending on the specification of the underlying estimation equation. This corresponds to a potential staff saving of between 12 and 36 
percent. In the case of the specification (3) with ASSETS as the output variable (first column in Table 6) which is the specification with the best overall fit, EU staff size is predicted to be $3188 .{ }^{4}$ This corresponds to a saving in staff and, hence, institutional costs of some 15 percent.

\section{Conclusions}

Against the background of the increasing integration of financial markets in the EU, the persisting fragmentation of financial supervision causes additional supervisory cost. These include institutional costs, firm's compliance costs, and opportunity costs. The aim of this paper is to assess these costs of supervisory fragmentation and, as a consequence, the extent of potential cost savings with a cost-efficient European supervisory system.

In a first step we estimate supervisory cost functions employing a large crosscountry database. The results clearly indicate that there exists increasing economies of scale in banking supervision. An increase in supervisory output (measured by the size of the banking market) by one percent, causes institutional supervisory cost (measured by supervisory staff) to rise by only some 0.5 percent.

In a second step, we predict the staff size of a cost-efficient European supervisory system assuming that all economies of scale could be realised for the whole of the EU. In a plausible scenario the resulting savings would amount to a reduction of EU supervisory staff and, hence, of institutional supervisory cost of some 15 percent.

Taking predictions one step further, one can generalise the results obtained for the institutional costs to the other types of supervisory cost. There is a strong link between the institutional costs, for which we quantified cost savings and the costs of compliance that can be attributed to the regulated firms. Institutional costs are born by the regulated industry through fees, which constitute direct compliance costs. Thus, a reduction in institutional costs on the one hand, means a reduction in the firm's direct compliance costs on the other. Besides, since supervisory agencies demand information which financial companies have to supply, overall compliance costs at the firm level should rise with the size and the budget of the supervisory agency. ${ }^{5}$ Thus, even if the predicted savings in

${ }^{4}$ Note that specification (4) with ASSETS as the output variable has a slightly higher Rsquared. However, in this specification the variable MULTI is included which is insignificant and does take the wrong sign.

${ }^{5}$ Based on a survey Franks et al. (1998) reports average ratios of total compliance costs to institutional costs of 4.7 for investment management firms and 7.1 for securities firms. In 
supervisory staff appear to be modest in absolute terms it hints to much higher cost savings in the economy as a whole. Overall, the analysis in this paper provides clear empirical evidence for the existence of economies of scale in financial supervision.

the context of the UK's Financial Services Act Lomax (1987) estimates compliance costs to be five times as much as direct costs. 


\section{References}

Alfon, I. and P. Andrews (1999), Cost-Benefit Analysis in Financial Regulation, FSA Occasional Paper Series 3, September 1999, London.

Barth, J.R., Dopico, L.G., Nolle, D.E. and Wilcox, J.A. (2002). An International Comparison and Assessment of the Structure of Bank Supervision. Mimeo.

Briault, C. (2003), The Costs of Financial Regulation, Speech given at the ZEW/AEI Conference on "Regulation and Supervision of Financial Markets and Institutions in the EU”, 10 July 2003, Mannheim.

Elliehausen, G. (1998), The Cost of Bank Regulation: A Review of the Evidence, Staff Studies 171, Board of Governors of the Federal Reserve System, April 1998, Washington D.C.

European Central Bank (2002), Structural analysis of EU banking sector - Year 2001, November 2002, Frankfurt.

European Commission (2002), Report by the Economic and Financial Committee (EFC) on EU financial integration, Economic Papers No. 171, May.

Forum Group (2002), Reporting Requirements, Findings of the Forum Group n¹0, Final Synthesis Report, 14 October 2002.

Franks, J.R., S.M. Schaefer and M.D. Stauton (1998), The Direct and Compliance Costs of Financial Regulation, Journal of Banking \& Finance 21, 1547-1572.

Goodhart, C., P. Hartmann, D. Llewellyn, L. Rojas-Suárez and S. Weibrod (1998), Financial Regulation - Why, how and where now?, Routledge, London.

Goodhart, C., D. Schoenmaker and P. Dasgupta (2002), The Skill Profile of Central Bankers and Supervisors, European Finance Review 6, 397-427.

Gual, J. (2004), The Integration of EU Banking Markets, CEPR Discussion Paper No. 4212.

Heinemann, F. and M. Jopp (2002), The benefits of a working European retail market for financial services, Europa Union Verlag, Bonn.

Lomax, D.F. (1987), London Markets after the Financial Services Act, Butterworths, London. 


\section{Figures and Tables}

Figure 1: Systematisation of the Costs of Financial Regulation

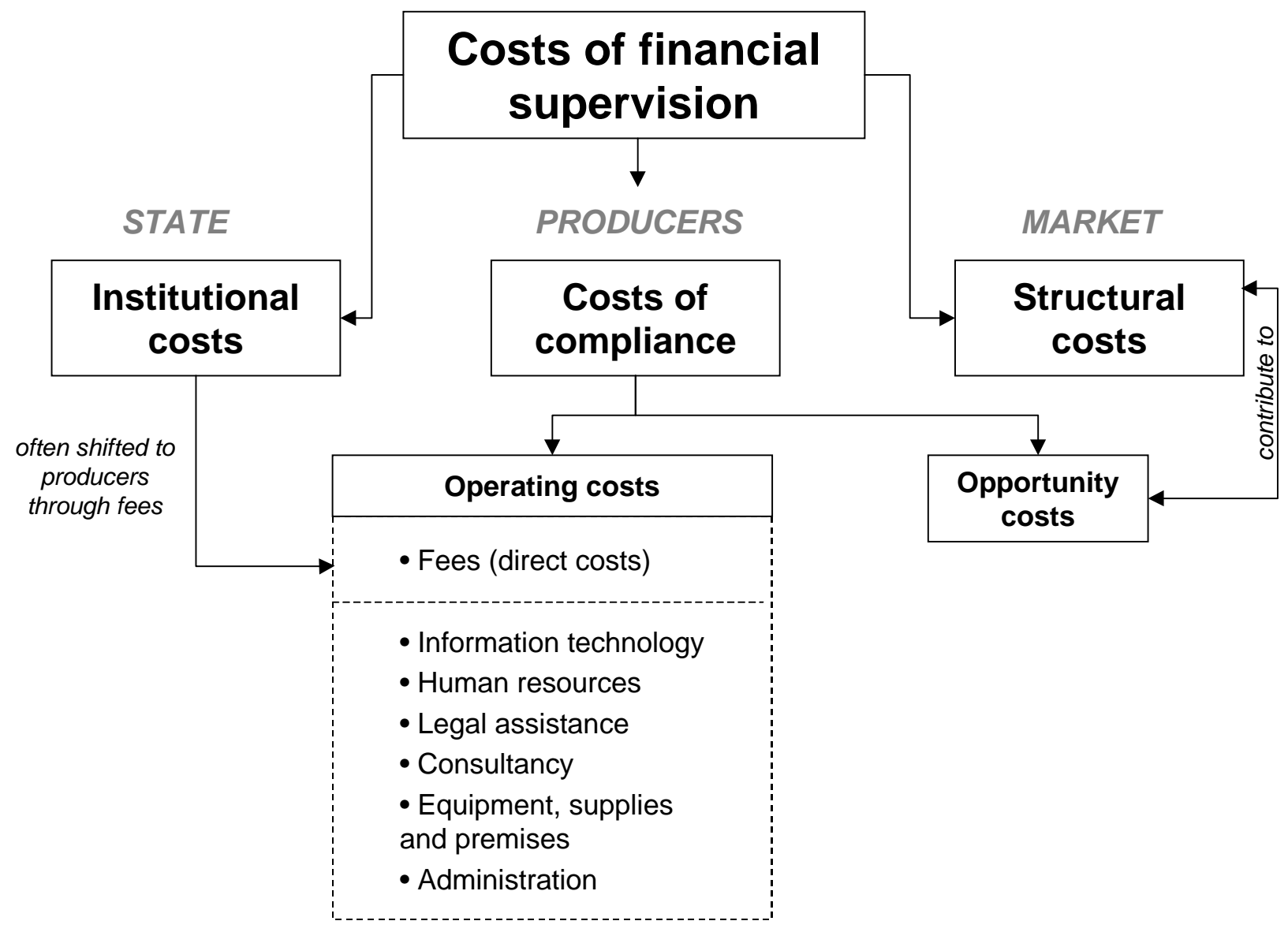


Table 1: Estimation results with STAFF as the dependant variable and ASSETS as the supervisory output variable

\begin{tabular}{|c|c|c|c|c|c|c|c|c|c|}
\hline & (1) & (2) & (3) & (4) & (5) & (6) & (7) & (8) & (9) \\
\hline ASSETS & $\begin{array}{c}0.5115^{* * * *} \\
(0.000)\end{array}$ & $\begin{array}{c}0.5034^{* * * *} \\
(0.000)\end{array}$ & $\begin{array}{c}0.5009 * * * \\
(0.000)\end{array}$ & $\begin{array}{c}0.5024^{* * *} \\
(0.000)\end{array}$ & $\begin{array}{c}0.5087 * * * \\
(0.000)\end{array}$ & $\begin{array}{c}0.5108^{* * *} \\
(0.000)\end{array}$ & $\begin{array}{c}0.4825^{* * *} \\
(0.000)\end{array}$ & $\begin{array}{c}0.4978 * * * \\
(0.000)\end{array}$ & $\begin{array}{c}0.5040 * * * \\
(0.000)\end{array}$ \\
\hline HOMOGEN & $\begin{array}{c}-0.4984 * \\
(0.054)\end{array}$ & $\begin{array}{c}-0.5951^{* * *} \\
(0.010)\end{array}$ & $\begin{array}{c}-0.5706^{* *} \\
(0.016)\end{array}$ & $\begin{array}{c}-0.5777^{* *} \\
(0.014)\end{array}$ & $\begin{array}{c}-0.4992 * \\
(0.053)\end{array}$ & $\begin{array}{c}-0.4926^{*} \\
(0.051)\end{array}$ & $\begin{array}{l}-0.2832 \\
(0.335)\end{array}$ & $\begin{array}{l}-0.3791 \\
(0.137)\end{array}$ & $\begin{array}{l}-0.3958 \\
(0.124)\end{array}$ \\
\hline CONCA & $\begin{array}{l}-0.2677 \\
(0.157)\end{array}$ & $\begin{array}{c}-0.3290 * \\
(0.075)\end{array}$ & $\begin{array}{c}-0.3415^{* *} \\
(0.050)\end{array}$ & $\begin{array}{c}-0.3475^{*} \\
(0.051)\end{array}$ & $\begin{array}{c}-0.2674 \\
(0.155)\end{array}$ & $\begin{array}{l}-0.2475 \\
(0.195)\end{array}$ & & & \\
\hline DRATES & & & & & & & $\begin{array}{l}0.0595 \\
(0.492)\end{array}$ & $\begin{array}{l}0.0921 \\
(0.263)\end{array}$ & $\begin{array}{l}0.0884 \\
(0.280)\end{array}$ \\
\hline NPL & $\begin{array}{l}0.1002 \\
(0.145)\end{array}$ & & & & $\begin{array}{l}0.0956 \\
(0.153)\end{array}$ & $\begin{array}{c}0.1230 * * \\
(0.049)\end{array}$ & $\begin{array}{l}0.1009 \\
(0.179)\end{array}$ & & \\
\hline MULTI & $\begin{array}{l}-0.1099 \\
(0.663)\end{array}$ & & & $\begin{array}{l}-0.0818 \\
(0.713)\end{array}$ & & $\begin{array}{l}-0.0700 \\
(0.784)\end{array}$ & $\begin{array}{l}0.1734 \\
(0.524)\end{array}$ & $\begin{array}{l}0.1843 \\
(0.432)\end{array}$ & \\
\hline $\mathrm{CB}$ & $\begin{array}{l}0.2461 \\
(0.101)\end{array}$ & & $\begin{array}{c}0.3193 * * \\
(0.015)\end{array}$ & $\begin{array}{c}0.3301 * * \\
(0.012)\end{array}$ & $\begin{array}{l}0.2368 \\
(0.121)\end{array}$ & & $\begin{array}{l}0.2254 \\
(0.146)\end{array}$ & $\begin{array}{c}0.3147^{* *} \\
(0.018)\end{array}$ & $\begin{array}{c}0.3442 * * \\
(0.011)\end{array}$ \\
\hline DI & $\begin{array}{c}0.4719 * * * \\
(0.001)\end{array}$ & $\begin{array}{c}0.4141^{* * *} \\
(0.003)\end{array}$ & $\begin{array}{c}0.4861^{* * *} \\
(0.001)\end{array}$ & $\begin{array}{c}0.4926^{* * *} \\
(0.001)\end{array}$ & $\begin{array}{c}0.4623 * * * \\
(0.001)\end{array}$ & $\begin{array}{c}0.4174^{* * *} \\
(0.002)\end{array}$ & $\begin{array}{c}0.4890^{* * *} \\
(0.001)\end{array}$ & $\begin{array}{c}0.5241^{* * *} \\
(0.001)\end{array}$ & $\begin{array}{c}0.5393 * * * \\
(0.001)\end{array}$ \\
\hline GDPCAP & $\begin{array}{c}-0.4835 * * * \\
(0.000)\end{array}$ & $\begin{array}{c}-0.5317 * * * \\
(0.000)\end{array}$ & $\begin{array}{c}-0.5126 * * * \\
(0.000)\end{array}$ & $\begin{array}{c}-0.5136 * * * \\
(0.000)\end{array}$ & $\begin{array}{c}-0.4819 * * * \\
(0.000)\end{array}$ & $\begin{array}{c}-0.4885 * * * \\
(0.000)\end{array}$ & $\begin{array}{c}-0.4904 * * * \\
(0.000)\end{array}$ & $\begin{array}{c}-0.5388 * * * \\
(0.000)\end{array}$ & $\begin{array}{c}-0.5467 * * * \\
(0.000)\end{array}$ \\
\hline Constant & $\begin{array}{c}-3.8370^{* * *} \\
(0.005)\end{array}$ & $\begin{array}{c}-2.7072 * * * \\
(0.036)\end{array}$ & $\begin{array}{c}-3.0020^{* *} \\
(0.018)\end{array}$ & $\begin{array}{c}-3.0081^{* *} \\
(0.018)\end{array}$ & $\begin{array}{c}-3.7800 * * * \\
(0.006)\end{array}$ & $\begin{array}{c}-3.7046 * * * \\
(0.007)\end{array}$ & $\begin{array}{c}-4.1424 * * * \\
(0.004)\end{array}$ & $\begin{array}{c}-4.1419 * * * \\
(0.001)\end{array}$ & $\begin{array}{c}-4.2278^{* * *} \\
(0.000)\end{array}$ \\
\hline R-squared & 0.6950 & 0.7016 & 0.7120 & 0.7124 & 0.6942 & 0.6890 & 0.6817 & 0.7031 & 0.7010 \\
\hline $\mathrm{N}$ & 140 & 153 & 150 & 150 & 140 & 143 & 123 & 135 & 135 \\
\hline
\end{tabular}

Notes: With the exception of the dummy variables MULTI, CB, and DI, all variables are taken in logarithms. P-values in parentheses; using

heteroskedasticity-consistent standard errors from OLS regressions; ***, **, * indicates 1, 5, 10\% significance level. 
Table 2: Estimation results with STAFF as the dependant variable and DEPOSITS as the supervisory output variable

\begin{tabular}{|c|c|c|c|c|c|c|c|c|c|}
\hline & (1) & (2) & (3) & (4) & (5) & (6) & (7) & (8) & (9) \\
\hline DEPOSITS & $\begin{array}{c}0.4887 * * * \\
(0.000)\end{array}$ & $\begin{array}{c}0.4885^{* * * *} \\
(0.000)\end{array}$ & $\begin{array}{c}0.4882^{* * *} \\
(0.000)\end{array}$ & $\begin{array}{c}0.4889 * * * \\
(0.000)\end{array}$ & $\begin{array}{c}0.4877 * * * \\
(0.000)\end{array}$ & $\begin{array}{c}0.4854^{* * *} \\
(0.000)\end{array}$ & $\begin{array}{c}0.4555^{* * *} \\
(0.000)\end{array}$ & $\begin{array}{c}0.4723 * * * \\
(0.000)\end{array}$ & $\begin{array}{c}0.4799 * * * \\
(0.000)\end{array}$ \\
\hline HOMOGEN & $\begin{array}{c}-0.4690 * \\
(0.087)\end{array}$ & $\begin{array}{c}-0.5746^{* *} \\
(0.016)\end{array}$ & $\begin{array}{c}-0.5517^{* *} \\
(0.023)\end{array}$ & $\begin{array}{c}-0.5544^{* *} \\
(0.021)\end{array}$ & $\begin{array}{c}-0.4696^{*} \\
(0.085)\end{array}$ & $\begin{array}{c}-0.4665^{*} \\
(0.081)\end{array}$ & $\begin{array}{l}-0.1897 \\
(0.559)\end{array}$ & $\begin{array}{l}-0.2750 \\
(0.334)\end{array}$ & $\begin{array}{l}-0.2957 \\
(0.301)\end{array}$ \\
\hline CONCD & $\begin{array}{c}-0.1710^{* * * *} \\
(0.000)\end{array}$ & $\begin{array}{c}-0.1895 * * * \\
(0.000)\end{array}$ & $\begin{array}{c}-0.1885^{* * *} \\
(0.000)\end{array}$ & $\begin{array}{c}-0.1887 * * * \\
(0.000)\end{array}$ & $\begin{array}{c}-0.1716^{* * *} \\
(0.000)\end{array}$ & $\begin{array}{c}-0.1692 * * * \\
(0.000)\end{array}$ & & & \\
\hline DRATES & & & & & & & $\begin{array}{l}0.1041 \\
(0.372)\end{array}$ & $\begin{array}{l}0.1365 \\
(0.226)\end{array}$ & $\begin{array}{l}0.1322 \\
(0.233)\end{array}$ \\
\hline NPL & $\begin{array}{l}0.0934 \\
(0.182)\end{array}$ & & & & $\begin{array}{l}0.0916 \\
(0.178)\end{array}$ & $\begin{array}{l}0.1140^{*} \\
(0.072)\end{array}$ & $\begin{array}{l}0.1099 \\
(0.171)\end{array}$ & & \\
\hline MULTI & $\begin{array}{l}-0.0410 \\
(0.886)\end{array}$ & & & $\begin{array}{l}-0.0274 \\
(0.912)\end{array}$ & & $\begin{array}{l}-0.0017 \\
(0.995)\end{array}$ & $\begin{array}{l}0.2522 \\
(0.404)\end{array}$ & $\begin{array}{l}0.2433 \\
(0.352)\end{array}$ & \\
\hline $\mathrm{CB}$ & $\begin{array}{l}0.2358 \\
(0.123)\end{array}$ & & $\begin{array}{c}0.3093 * * \\
(0.021)\end{array}$ & $\begin{array}{c}0.3128 * * \\
(0.018)\end{array}$ & $\begin{array}{l}0.2324 \\
(0.136)\end{array}$ & & $\begin{array}{l}0.1973 \\
(0.220)\end{array}$ & $\begin{array}{c}0.2889 * * \\
(0.035)\end{array}$ & $\begin{array}{c}0.3275^{* *} \\
(0.018)\end{array}$ \\
\hline DI & $\begin{array}{c}0.5710^{* * *} \\
(0.000)\end{array}$ & $\begin{array}{c}0.5211^{* * *} \\
(0.000)\end{array}$ & $\begin{array}{c}0.5905^{* * *} \\
(0.000)\end{array}$ & $\begin{array}{c}0.5927 * * * \\
(0.000)\end{array}$ & $\begin{array}{c}0.5672 * * * \\
(0.000)\end{array}$ & $\begin{array}{c}0.5175^{* * *} \\
(0.000)\end{array}$ & $\begin{array}{c}0.5423^{* * *} \\
(0.001)\end{array}$ & $\begin{array}{c}0.5862 * * * \\
(0.000)\end{array}$ & $\begin{array}{c}0.6076^{* * *} \\
(0.000)\end{array}$ \\
\hline GDPCAP & $\begin{array}{c}-0.4530 * * * \\
(0.000)\end{array}$ & $\begin{array}{c}-0.5034^{* * * *} \\
(0.000)\end{array}$ & $\begin{array}{c}-0.4871 * * * \\
(0.000)\end{array}$ & $\begin{array}{c}-0.4875^{* * *} \\
(0.000)\end{array}$ & $\begin{array}{c}-0.4525 * * * \\
(0.000)\end{array}$ & $\begin{array}{c}-0.4552 * * * \\
(0.000)\end{array}$ & $\begin{array}{c}-0.4375 * * * \\
(0.000)\end{array}$ & $\begin{array}{c}-0.4891^{* * * *} \\
(0.000)\end{array}$ & $\begin{array}{c}-0.4986 * * * \\
(0.000)\end{array}$ \\
\hline Constant & $\begin{array}{c}-3.7393 * * * \\
(0.000)\end{array}$ & $\begin{array}{c}-2.9746 * * * \\
(0.000)\end{array}$ & $\begin{array}{c}-3.3448 * * * \\
(0.000)\end{array}$ & $\begin{array}{c}-3.3577 * * * \\
(0.000)\end{array}$ & $\begin{array}{c}-3.7155 * * * \\
(0.000)\end{array}$ & $\begin{array}{c}-3.4993 * * * \\
(0.000)\end{array}$ & $\begin{array}{c}-3.7916^{* *} \\
(0.014)\end{array}$ & $\begin{array}{c}-3.7755^{* * *} \\
(0.004)\end{array}$ & $\begin{array}{c}-3.8806 * * * \\
(0.000)\end{array}$ \\
\hline R-squared & 0.6529 & 0.6642 & 0.6741 & 0.6741 & 0.6528 & 0.6472 & 0.6340 & 0.6594 & 0.6558 \\
\hline $\mathrm{N}$ & 140 & 153 & 150 & 150 & 140 & 143 & 123 & 135 & 135 \\
\hline
\end{tabular}

Notes: With the exception of the dummy variables MULTI, CB, and DI, all variables are taken in logarithms. P-values in parentheses; using

heteroskedasticity-consistent standard errors from OLS regressions; ***, **, * indicates 1, 5, 10\% significance level. 
Table 3: Estimation results with STAFF as the dependant variable and CLAIMS as the supervisory output variable

\begin{tabular}{|c|c|c|c|c|c|c|c|c|c|}
\hline & (1) & (2) & (3) & (4) & (5) & (6) & (7) & (8) & (9) \\
\hline CLAIMS & $\begin{array}{c}0.4187 * * * \\
(0.000)\end{array}$ & $\begin{array}{c}0.4190 * * * \\
(0.000)\end{array}$ & $\begin{array}{c}0.4180 * * * \\
(0.000)\end{array}$ & $\begin{array}{c}0.4633 * * * \\
(0.000)\end{array}$ & $\begin{array}{c}0.4556^{* * * *} \\
(0.000)\end{array}$ & $\begin{array}{c}0.4554 * * * \\
(0.000)\end{array}$ & $\begin{array}{c}0.4784^{* * *} \\
(0.000)\end{array}$ & $\begin{array}{c}0.4948 * * * \\
(0.000)\end{array}$ & $\begin{array}{c}0.4991 * * * \\
(0.000)\end{array}$ \\
\hline HOMOGEN & $\begin{array}{c}-0.4962 * \\
(0.058)\end{array}$ & $\begin{array}{c}-0.5090 * * \\
(0.030)\end{array}$ & $\begin{array}{c}-0.5051^{* *} \\
(0.033)\end{array}$ & $\begin{array}{c}-0.6221^{* *} \\
(0.023)\end{array}$ & $\begin{array}{c}-0.6672 * * * \\
(0.006)\end{array}$ & $\begin{array}{c}-0.6664 * * * \\
(0.007)\end{array}$ & $\begin{array}{l}-0.4106 \\
(0.177)\end{array}$ & $\begin{array}{c}-0.5011 * \\
(0.069)\end{array}$ & $\begin{array}{c}-0.5162 * \\
(0.065)\end{array}$ \\
\hline CONCA & $\begin{array}{c}-0.6359 * * * \\
(0.004)\end{array}$ & $\begin{array}{c}-0.6586^{* * * *} \\
(0.001)\end{array}$ & $\begin{array}{c}-0.6530 * * * \\
(0.001)\end{array}$ & & & & & & \\
\hline CONCD & & & & $\begin{array}{c}-0.2229 * * \\
(0.014)\end{array}$ & $\begin{array}{c}-0.2389 * * \\
(0.012)\end{array}$ & $\begin{array}{c}-0.2388^{* *} \\
(0.012)\end{array}$ & & & \\
\hline DRATES & & & & & & & $\begin{array}{l}0.0035 \\
(0.971)\end{array}$ & $\begin{array}{l}0.0308 \\
(0.744)\end{array}$ & $\begin{array}{l}0.0274 \\
(0.767)\end{array}$ \\
\hline NPL & $\begin{array}{l}0.0383 \\
(0.589)\end{array}$ & & & $\begin{array}{l}0.0364 \\
(0.603)\end{array}$ & & & $\begin{array}{l}0.0767 \\
(0.250)\end{array}$ & & \\
\hline MULTI & $\begin{array}{l}-0.0582 \\
(0.825)\end{array}$ & $\begin{array}{l}-0.0607 \\
(0.793)\end{array}$ & & $\begin{array}{l}-0.0214 \\
(0.936)\end{array}$ & $\begin{array}{l}-0.0085 \\
(0.971)\end{array}$ & & $\begin{array}{l}0.1556 \\
(0.547)\end{array}$ & $\begin{array}{l}0.1282 \\
(0.555)\end{array}$ & \\
\hline CB & $\begin{array}{c}0.2830 * \\
(0.067)\end{array}$ & $\begin{array}{c}0.3421^{* * *} \\
(0.010)\end{array}$ & $\begin{array}{c}0.3328 * * \\
(0.011)\end{array}$ & $\begin{array}{c}0.2660 * \\
(0.082)\end{array}$ & $\begin{array}{c}0.3224 * * \\
(0.014)\end{array}$ & $\begin{array}{c}0.3211^{* *} \\
(0.015)\end{array}$ & $\begin{array}{l}0.2374 \\
(0.122)\end{array}$ & $\begin{array}{c}0.2983^{* *} \\
(0.026)\end{array}$ & $\begin{array}{c}0.3195 * * \\
(0.019)\end{array}$ \\
\hline $\mathrm{DI}$ & $\begin{array}{c}0.6274 * * * \\
(0.000)\end{array}$ & $\begin{array}{c}0.6486 * * * \\
(0.000)\end{array}$ & $\begin{array}{c}0.6438 * * * \\
(0.000)\end{array}$ & $\begin{array}{c}0.6654^{* * *} \\
(0.000)\end{array}$ & $\begin{array}{c}0.6852 * * * \\
(0.000)\end{array}$ & $\begin{array}{c}0.6815 * * * \\
(0.000)\end{array}$ & $\begin{array}{c}0.6439 * * * \\
(0.000)\end{array}$ & $\begin{array}{c}0.6410 * * * \\
(0.000)\end{array}$ & $\begin{array}{c}0.6533 * * * \\
(0.000)\end{array}$ \\
\hline GDPCAP & $\begin{array}{c}-0.4206 * * * \\
(0.000)\end{array}$ & $\begin{array}{c}-0.4388 * * * \\
(0.000)\end{array}$ & $\begin{array}{c}-0.4378 * * * \\
(0.000)\end{array}$ & $\begin{array}{c}-0.4451 * * * \\
(0.000)\end{array}$ & $\begin{array}{c}-0.4628 * * * \\
(0.000)\end{array}$ & $\begin{array}{c}-0.4626 * * * \\
(0.000)\end{array}$ & $\begin{array}{c}-0.5062 * * * \\
(0.000)\end{array}$ & $\begin{array}{c}-0.5438 * * * \\
(0.000)\end{array}$ & $\begin{array}{c}-0.5491^{* * *} \\
(0.000)\end{array}$ \\
\hline Constant & $\begin{array}{l}-0.3131 \\
(0.846)\end{array}$ & $\begin{array}{l}-0.0822 \\
(0.956)\end{array}$ & $\begin{array}{l}-0.0854 \\
(0.954)\end{array}$ & $\begin{array}{c}-2.6811 * * * \\
(0.008)\end{array}$ & $\begin{array}{c}-2.5442 * * * \\
(0.010)\end{array}$ & $\begin{array}{c}-2.5405^{* * *} \\
(0.010)\end{array}$ & $\begin{array}{c}-3.5851^{* * *} \\
(0.001)\end{array}$ & $\begin{array}{c}-3.6783 * * * \\
(0.000)\end{array}$ & $\begin{array}{c}-3.7359 * * * \\
(0.000)\end{array}$ \\
\hline R-squared & 0.6744 & 0.6997 & 0.6994 & 0.6648 & 0.6890 & 0.6890 & 0.6777 & 0.6942 & 0.6932 \\
\hline $\mathrm{N}$ & 138 & 148 & 148 & 138 & 148 & 148 & 123 & 138 & 138 \\
\hline
\end{tabular}

Notes: With the exception of the dummy variables MULTI, CB, and DI, all variables are taken in logarithms. P-values in parentheses; using heteroskedasticity-consistent standard errors from OLS regressions; ***, **, * indicates $1,5,10 \%$ significance level. 
Table 4: Estimation results with STAFF as the dependant variable and BANKS as the supervisory output variable

\begin{tabular}{|c|c|c|c|c|c|c|c|c|c|}
\hline & (1) & (2) & (3) & (4) & (5) & (6) & (7) & (8) & (9) \\
\hline BANKS & $\begin{array}{c}0.5904 * * * \\
(0.000)\end{array}$ & $\begin{array}{c}0.5516^{* * *} \\
(0.000)\end{array}$ & $\begin{array}{c}0.5492 * * * \\
(0.000)\end{array}$ & $\begin{array}{c}0.6397 * * * \\
(0.000)\end{array}$ & $\begin{array}{c}0.6171^{* * * *} \\
(0.000)\end{array}$ & $\begin{array}{c}0.6149 * * * \\
(0.000)\end{array}$ & $\begin{array}{c}0.6194 * * * \\
(0.000)\end{array}$ & $\begin{array}{c}0.5964 * * * \\
(0.000)\end{array}$ & $\begin{array}{c}0.6046 * * * \\
(0.000)\end{array}$ \\
\hline HOMOGEN & $\begin{array}{l}-0.3016 \\
(0.325)\end{array}$ & $\begin{array}{c}-0.4176 \\
(0.137)\end{array}$ & $\begin{array}{l}-0.4126 \\
(0.144)\end{array}$ & $\begin{array}{l}-0.3520 \\
(0.259)\end{array}$ & $\begin{array}{c}-0.5059 * \\
(0.069)\end{array}$ & $\begin{array}{c}-0.5021^{*} \\
(0.073)\end{array}$ & $\begin{array}{l}-0.2849 \\
(0.393)\end{array}$ & $\begin{array}{c}-0.5482 * \\
(0.065)\end{array}$ & $\begin{array}{c}-0.5649 * \\
(0.061)\end{array}$ \\
\hline CONCA & $\begin{array}{l}-0.3725 \\
(0.177)\end{array}$ & $\begin{array}{c}-0.4746 * \\
(0.075)\end{array}$ & $\begin{array}{c}-0.4720 * \\
(0.076)\end{array}$ & & & & & & \\
\hline CONCD & & & & $\begin{array}{c}-0.1181^{* *} \\
(0.035)\end{array}$ & $\begin{array}{c}-0.1428^{* *} \\
(0.014)\end{array}$ & $\begin{array}{c}-0.1432^{* *} \\
(0.013)\end{array}$ & & & \\
\hline DRATES & & & & & & & $\begin{array}{l}0.6194 \\
(0.232)\end{array}$ & $\begin{array}{l}-0.1678 \\
(0.129)\end{array}$ & $\begin{array}{c}-0.1735 \\
(0.124)\end{array}$ \\
\hline NPL & $\begin{array}{c}0.1564 * \\
(0.080)\end{array}$ & & & $\begin{array}{l}0.1631 * \\
(0.065)\end{array}$ & & & $\begin{array}{c}0.2077 * * \\
(0.024)\end{array}$ & & \\
\hline MULTI & $\begin{array}{l}-0.0435 \\
(0.874)\end{array}$ & $\begin{array}{l}-0.0635 \\
(0.807)\end{array}$ & & $\begin{array}{c}-0.0346 \\
(0.900)\end{array}$ & $\begin{array}{l}-0.0452 \\
(0.863)\end{array}$ & & $\begin{array}{l}0.2064 \\
(0.475)\end{array}$ & $\begin{array}{l}0.1533 \\
(0.572)\end{array}$ & \\
\hline $\mathrm{CB}$ & $\begin{array}{l}0.0806 \\
(0.650)\end{array}$ & $\begin{array}{l}0.2056 \\
(0.207)\end{array}$ & $\begin{array}{l}0.1978 \\
(0.226)\end{array}$ & $\begin{array}{l}0.0575 \\
(0.741)\end{array}$ & $\begin{array}{l}0.1786 \\
(0.266)\end{array}$ & $\begin{array}{l}0.1733 \\
(0.282)\end{array}$ & $\begin{array}{l}-0.0567 \\
(0.747)\end{array}$ & $\begin{array}{l}0.0851 \\
(0.610)\end{array}$ & $\begin{array}{l}0.1081 \\
(0.517)\end{array}$ \\
\hline DI & $\begin{array}{c}0.5643 * * * \\
(0.001)\end{array}$ & $\begin{array}{c}0.6360 * * * \\
(0.000)\end{array}$ & $\begin{array}{c}0.6313 * * * \\
(0.000)\end{array}$ & $\begin{array}{c}0.5661^{* * * *} \\
(0.001)\end{array}$ & $\begin{array}{c}0.6349 * * * \\
(0.000)\end{array}$ & $\begin{array}{c}0.6318^{* * *} \\
(0.000)\end{array}$ & $\begin{array}{c}0.5684^{* * *} \\
(0.002)\end{array}$ & $\begin{array}{c}0.6440 * * * \\
(0.000)\end{array}$ & $\begin{array}{c}0.6571^{* * * *} \\
(0.000)\end{array}$ \\
\hline GDPCAP & $\begin{array}{l}-0.0712 \\
(0.303)\end{array}$ & $\begin{array}{c}-0.1206 * \\
(0.066)\end{array}$ & $\begin{array}{c}-0.1205^{*} \\
(0.065)\end{array}$ & $\begin{array}{c}-0.0743 \\
(0.284)\end{array}$ & $\begin{array}{c}-0.1289 * * \\
(0.048)\end{array}$ & $\begin{array}{c}-0.1287 * * \\
(0.047)\end{array}$ & $\begin{array}{l}-0.0987 \\
(0.236)\end{array}$ & $\begin{array}{c}-0.1852^{* * *} \\
(0.014)\end{array}$ & $\begin{array}{c}-0.1886 * * \\
(0.013)\end{array}$ \\
\hline Constant & $\begin{array}{c}3.4569 * * \\
(0.011)\end{array}$ & $\begin{array}{c}4.4440 * * * \\
(0.001)\end{array}$ & $\begin{array}{c}4.4415^{* * *} \\
(0.001)\end{array}$ & $\begin{array}{c}2.2445^{* * *} \\
(0.000)\end{array}$ & $\begin{array}{c}2.8973 * * * \\
(0.000)\end{array}$ & $\begin{array}{c}2.9056^{* * *} \\
(0.000)\end{array}$ & $\begin{array}{c}2.2737 * * * \\
(0.006)\end{array}$ & $\begin{array}{c}3.1395 * * * \\
(0.000)\end{array}$ & $\begin{array}{c}3.1414 * * * \\
(0.000)\end{array}$ \\
\hline R-squared & 0.5511 & 0.5680 & 0.5677 & 0.5490 & 0.5633 & 0.5632 & 0.5750 & 0.5690 & 0.5675 \\
\hline $\mathrm{N}$ & 140 & 150 & 150 & 140 & 150 & 150 & 123 & 138 & 138 \\
\hline
\end{tabular}

Notes: With the exception of the dummy variables MULTI, CB, and DI, all variables are taken in logarithms. P-values in parentheses; using heteroskedasticity-consistent standard errors from OLS regressions; ***, **, * indicates 1, 5, 10\% significance level. 
Table 5: Estimation results with BUDGET as the dependant variable

\begin{tabular}{|c|c|c|c|c|c|c|c|c|c|c|}
\hline & (1) & (2) & (3) & (4) & (5) & (6) & (7) & (8) & (9) & (10) \\
\hline ASSETS & $\begin{array}{c}0.4654 * * * \\
(0.000)\end{array}$ & $\begin{array}{c}0.4754 * * * \\
(0.000)\end{array}$ & & & & & & & & \\
\hline DEPOSITS & & & $\begin{array}{c}0.4561^{* * *} \\
(0.000)\end{array}$ & $\begin{array}{c}0.4608^{* * *} \\
(0.000)\end{array}$ & & & & & & \\
\hline CLAIMS & & & & & $\begin{array}{c}0.4744 * * * \\
(0.000)\end{array}$ & $\begin{array}{c}0.4916 * * * \\
(0.000)\end{array}$ & $\begin{array}{c}0.5194^{* * * *} \\
(0.000)\end{array}$ & & & \\
\hline BANKS & & & & & & & & $\begin{array}{c}0.5365^{* * *} \\
(0.001)\end{array}$ & $\begin{array}{c}0.4881^{* * * *} \\
(0.000)\end{array}$ & $\begin{array}{c}0.5058 * * * \\
(0.000)\end{array}$ \\
\hline HOMOGEN & $\begin{array}{l}0.4657 \\
(0.451)\end{array}$ & $\begin{array}{l}0.2899 \\
(0.674)\end{array}$ & $\begin{array}{l}0.3235 \\
(0.598)\end{array}$ & $\begin{array}{l}0.2547 \\
(0.709)\end{array}$ & $\begin{array}{l}0.4959 \\
(0.431)\end{array}$ & $\begin{array}{l}0.6465 \\
(0.254)\end{array}$ & $\begin{array}{l}0.5611 \\
(0.354)\end{array}$ & $\begin{array}{l}0.4234 \\
(0.514)\end{array}$ & $\begin{array}{l}0.5291 \\
(0.375)\end{array}$ & $\begin{array}{l}0.3512 \\
(0.575)\end{array}$ \\
\hline CONCA & $\begin{array}{l}-0.3192 \\
(0.429)\end{array}$ & & & & $\begin{array}{c}-0.5179 * \\
(0.084)\end{array}$ & & & $\begin{array}{l}-0.2027 \\
(0.660)\end{array}$ & & \\
\hline CONCD & & & $\begin{array}{c}-0.2630 * * * \\
(0.000)\end{array}$ & & & $\begin{array}{c}-0.2534 * * * \\
(0.000)\end{array}$ & & & $\begin{array}{c}-0.1685^{* *} \\
(0.032)\end{array}$ & \\
\hline DRATES & & $\begin{array}{c}0.5996 * * * \\
(0.000)\end{array}$ & & $\begin{array}{c}0.6309 * * * \\
(0.000)\end{array}$ & & & $\begin{array}{c}0.4791 * * * \\
(0.002)\end{array}$ & & & $\begin{array}{l}0.3830 * \\
(0.054)\end{array}$ \\
\hline NPL & $\begin{array}{r}-0.0810 \\
(0.551)\end{array}$ & $\begin{array}{c}-0.2182 * \\
(0.088)\end{array}$ & $\begin{array}{r}-0.1129 \\
(0.405)\end{array}$ & $\begin{array}{c}-0.2302 * \\
(0.070)\end{array}$ & $\begin{array}{l}-0.1069 \\
(0.414)\end{array}$ & & & $\begin{array}{l}-0.0240 \\
(0.862)\end{array}$ & & \\
\hline MULTI & $\begin{array}{l}-0.0045 \\
(0.995)\end{array}$ & $\begin{array}{l}0.1997 \\
(0.817)\end{array}$ & $\begin{array}{l}0.0167 \\
(0.982)\end{array}$ & $\begin{array}{l}0.2017 \\
(0.815)\end{array}$ & $\begin{array}{l}-0.2192 \\
(0.797)\end{array}$ & $\begin{array}{l}-0.3622 \\
() 0.640\end{array}$ & $\begin{array}{l}0.0148 \\
(0.985)\end{array}$ & $\begin{array}{l}0.0730 \\
(0.920)\end{array}$ & $\begin{array}{l}-0.0902 \\
(0.895)\end{array}$ & $\begin{array}{l}0.2572 \\
(0.738)\end{array}$ \\
\hline CB & $\begin{array}{l}-0.2184 \\
(0.617)\end{array}$ & $\begin{array}{l}-0.1628 \\
(0.704)\end{array}$ & $\begin{array}{l}-0.1980 \\
(0.652)\end{array}$ & $\begin{array}{l}-0.1381 \\
(0.748)\end{array}$ & $\begin{array}{l}-0.1319 \\
(0.760)\end{array}$ & $\begin{array}{l}-0.1851 \\
(0.648)\end{array}$ & $\begin{array}{l}-0.4398 \\
(0.347)\end{array}$ & $\begin{array}{l}-0.2660 \\
(0.543)\end{array}$ & $\begin{array}{l}-0.2865 \\
(0.484)\end{array}$ & $\begin{array}{l}-0.6350 \\
(0.183)\end{array}$ \\
\hline DI & $\begin{array}{c}0.8281^{* *} \\
(0.016)\end{array}$ & $\begin{array}{c}0.6033 * * \\
(0.038)\end{array}$ & $\begin{array}{c}0.9702 * * * \\
(0.006)\end{array}$ & $\begin{array}{c}0.6746^{* *} \\
(0.021)\end{array}$ & $\begin{array}{c}0.9580^{* * * *} \\
(0.004)\end{array}$ & $\begin{array}{c}1.0606 * * * \\
(0.002)\end{array}$ & $\begin{array}{c}0.6752 * \\
(0.062)\end{array}$ & $\begin{array}{c}0.7537 * * \\
(0.033)\end{array}$ & $\begin{array}{c}0.8731^{* *} \\
(0.015)\end{array}$ & $\begin{array}{l}0.5820 \\
(0.120)\end{array}$ \\
\hline GDPCAP & $\begin{array}{l}-0.0193 \\
(0.893)\end{array}$ & $\begin{array}{l}-0.0150 \\
(0.904)\end{array}$ & $\begin{array}{r}-0.0080 \\
(0.947)\end{array}$ & $\begin{array}{l}0.0137 \\
(0.906)\end{array}$ & $\begin{array}{l}-0.0577 \\
(0.658)\end{array}$ & $\begin{array}{l}-0.0624 \\
(0.579)\end{array}$ & $\begin{array}{l}0.0244 \\
(0.826)\end{array}$ & $\begin{array}{c}0.3887 * * * \\
(0.002)\end{array}$ & $\begin{array}{c}0.3605^{* * * *} \\
(0.000)\end{array}$ & $\begin{array}{c}0.4547 * * * \\
(0.000)\end{array}$ \\
\hline Constant & $\begin{array}{l}5.2897 * \\
(0.075)\end{array}$ & $\begin{array}{l}2.9715 \\
(0.136)\end{array}$ & $\begin{array}{c}5.2764 * * * \\
(0.000)\end{array}$ & $\begin{array}{l}3.1973 \\
(0.116)\end{array}$ & $\begin{array}{c}6.5410^{* * * *} \\
(0.001)\end{array}$ & $\begin{array}{c}5.0043^{* * *} \\
(0.000)\end{array}$ & $\begin{array}{l}2.0286 \\
(0.224)\end{array}$ & $\begin{array}{c}10.802 * * * \\
(0.000)\end{array}$ & $\begin{array}{c}11.028^{* * *} \\
(0.000)\end{array}$ & $\begin{array}{c}8.9813 * * * \\
(0.000)\end{array}$ \\
\hline R-squared & 0.4969 & 0.5286 & 0.5053 & 0.5294 & 0.5529 & 0.5673 & 0.5189 & 0.4663 & 0.4749 & 0.4258 \\
\hline $\mathrm{N}$ & 85 & 80 & 85 & 80 & 84 & 89 & 89 & 85 & 90 & 89 \\
\hline
\end{tabular}

Notes: With the exception of the dummy variables MULTI, CB, and DI, all variables are taken in logarithms. P-values in parentheses; using

heteroskedasticity-consistent standard errors from OLS regressions; ***, **, * indicates 1, 5, 10\% significance level. 
Table 6: Predicted EU staff size and potential staff saving (in percent) in different scenarios

\begin{tabular}{|c|c|c|c|c|c|c|c|c|}
\hline \multirow[b]{2}{*}{$\begin{array}{l}\text { Scenarios (explanatory } \\
\text { variables assumptions) }\end{array}$} & \multicolumn{2}{|c|}{$\begin{array}{l}\text { ASSETS as output variable } \\
\text { (Table 1) }\end{array}$} & \multicolumn{2}{|c|}{$\begin{array}{l}\text { DEPOSITS as output variable } \\
\text { (Table 2) }\end{array}$} & \multicolumn{4}{|c|}{ CLAIMS as output variable (Table 3) } \\
\hline & $\begin{array}{c}\text { Specification } \\
\text { (3) }\end{array}$ & $\begin{array}{l}\text { Specification } \\
\text { (4) }\end{array}$ & $\begin{array}{c}\text { Specification } \\
(3)\end{array}$ & $\begin{array}{c}\text { Specification } \\
(4)\end{array}$ & $\begin{array}{l}\text { Specification } \\
(2)\end{array}$ & $\begin{array}{l}\text { Specification } \\
\text { (3) }\end{array}$ & $\begin{array}{l}\text { Specification } \\
\text { (5) }\end{array}$ & $\begin{array}{c}\text { Specification } \\
(6)\end{array}$ \\
\hline $\begin{array}{l}\text { 1. HOMOGEN and } \\
\text { CONCA/D: averages }\end{array}$ & $\begin{array}{c}900 \\
(-76.0)\end{array}$ & $\begin{array}{c}917 \\
(-75.6)\end{array}$ & $\begin{array}{c}794 \\
(-78.9)\end{array}$ & $\begin{array}{c}799 \\
(-78.7)\end{array}$ & $\begin{array}{c}665 \\
(-82.3)\end{array}$ & $\begin{array}{c}657 \\
(-82.5)\end{array}$ & $\begin{array}{c}717 \\
(-80.9)\end{array}$ & $\begin{array}{c}716 \\
(-80.9)\end{array}$ \\
\hline $\begin{array}{l}\text { 2. HOMOGEN }=0.33 \\
\text { CONCA/D: averages }\end{array}$ & $\begin{array}{c}1265 \\
(-66.3)\end{array}$ & $\begin{array}{c}1295 \\
(-65.5)\end{array}$ & $\begin{array}{c}1104 \\
(-70.6)\end{array}$ & $\begin{array}{c}1113 \\
(-70.4)\end{array}$ & $\begin{array}{c}902 \\
(-76.0)\end{array}$ & $\begin{array}{c}889 \\
(-76.3)\end{array}$ & $\begin{array}{c}1069 \\
(-71.5)\end{array}$ & $\begin{array}{l}1067 \\
(-71.6)\end{array}$ \\
\hline $\begin{array}{l}\text { 3. } \mathrm{HOMOGEN}=0.1 \\
\text { CONCA/D: averages }\end{array}$ & $\begin{array}{c}2501 \\
(-33.4)\end{array}$ & $\begin{array}{c}2581 \\
(-31.3)\end{array}$ & $\begin{array}{c}2133 \\
(-43.2)\end{array}$ & $\begin{array}{c}2157 \\
(-42.5)\end{array}$ & $\begin{array}{c}1656 \\
(-55.9)\end{array}$ & $\begin{array}{c}1624 \\
(-56.7)\end{array}$ & $\begin{array}{c}2371 \\
(-36.8)\end{array}$ & $\begin{array}{c}2364 \\
(-37.0)\end{array}$ \\
\hline $\begin{array}{l}\text { 4. HOMOGEN: average } \\
\text { CONCA } / D=20\end{array}$ & $\begin{array}{c}1147 \\
(-69.5)\end{array}$ & $\begin{array}{c}1173 \\
(-68.7)\end{array}$ & $\begin{array}{c}897 \\
(-76.1)\end{array}$ & $\begin{array}{c}903 \\
(-76.0)\end{array}$ & $\begin{array}{c}1062 \\
(-71.7)\end{array}$ & $\begin{array}{c}1045 \\
(-72.2)\end{array}$ & $\begin{array}{c}837 \\
(-77.7)\end{array}$ & $\begin{array}{c}836 \\
(-77.7)\end{array}$ \\
\hline $\begin{array}{l}\text { 5. HOMOGEN: average } \\
\text { CONCA } / D=10\end{array}$ & $\begin{array}{c}1453 \\
(-61.3)\end{array}$ & $\begin{array}{c}1493 \\
(-60.2)\end{array}$ & $\begin{array}{c}1022 \\
(-72.8)\end{array}$ & $\begin{array}{c}1029 \\
(-72.6)\end{array}$ & $\begin{array}{c}1676 \\
(-55.3)\end{array}$ & $\begin{array}{c}1643 \\
(-56.2)\end{array}$ & $\begin{array}{c}988 \\
(-73.7)\end{array}$ & $\begin{array}{c}986 \\
(-73.7)\end{array}$ \\
\hline $\begin{array}{l}\text { 6. } \text { HOMOGEN }=0.33 \\
\text { CONCA } / D=20\end{array}$ & $\begin{array}{c}1613 \\
(-57.0)\end{array}$ & $\begin{array}{c}1657 \\
(-55.9)\end{array}$ & $\begin{array}{c}1247 \\
(-66.8)\end{array}$ & $\begin{array}{c}1257 \\
(-66.5)\end{array}$ & $\begin{array}{c}1440 \\
(-61.7)\end{array}$ & $\begin{array}{c}1413 \\
(-62.4)\end{array}$ & $\begin{array}{c}1248 \\
(-66.8)\end{array}$ & $\begin{array}{c}1244 \\
(-66.8)\end{array}$ \\
\hline $\begin{array}{l}\text { 7. } \mathrm{HOMOGEN}=0.1 \\
\text { CONCA } / \mathrm{D}=20\end{array}$ & $\begin{array}{c}3188 \\
(-15.1)\end{array}$ & $\begin{array}{c}3303 \\
(-12.0)\end{array}$ & $\begin{array}{c}2410 \\
(-35.8)\end{array}$ & $\begin{array}{c}2437 \\
(-35.1)\end{array}$ & $\begin{array}{c}2643 \\
(-29.6)\end{array}$ & $\begin{array}{c}2583 \\
(-31.2)\end{array}$ & $\begin{array}{c}2767 \\
(-26.3)\end{array}$ & $\begin{array}{c}2758 \\
(-26.5)\end{array}$ \\
\hline $\begin{array}{l}\text { 8. } \mathrm{HOMOGEN}=0.33 \\
\operatorname{CONCA} / \mathrm{D}=10\end{array}$ & $\begin{array}{c}2044 \\
(-45.6)\end{array}$ & $\begin{array}{c}2109 \\
(-43.8)\end{array}$ & $\begin{array}{c}1421 \\
(-62.1)\end{array}$ & $\begin{array}{c}1432 \\
(-61.8)\end{array}$ & $\begin{array}{c}2272 \\
(-39.5)\end{array}$ & $\begin{array}{c}2222 \\
(-40.8)\end{array}$ & $\begin{array}{c}1472 \\
(-60.8)\end{array}$ & $\begin{array}{c}1469 \\
(-60.9)\end{array}$ \\
\hline $\begin{array}{l}\text { 9. } \mathrm{HOMOGEN}=0.1 \\
\text { CONCA } / \mathrm{D}=10\end{array}$ & $\begin{array}{l}4039 \\
(7.6)\end{array}$ & $\begin{array}{c}4203 \\
(12.0)\end{array}$ & $\begin{array}{c}2746 \\
(-26.9)\end{array}$ & $\begin{array}{c}2778 \\
(-26.0)\end{array}$ & $\begin{array}{c}4172 \\
(11.1)\end{array}$ & $\begin{array}{l}4061 \\
(8.2)\end{array}$ & $\begin{array}{c}3265 \\
(-13.0)\end{array}$ & $\begin{array}{c}3255 \\
(-13.3)\end{array}$ \\
\hline
\end{tabular}

Notes: All values refer to the year 2002. The relative staff savings (in parentheses) measure the excess staff (difference between the predicted staff size for the whole of the EU and the sum of the actual staff levels for every EU country which was 3754 in the year 2002) divided by the actual EU staff level. Thus, a negative percentage indicates a potential staff saving, i.e. the predicted EU staff size is lower than the actual EU staff level. 


\section{Appendix}

Table A1: Variables, definitions and sources

\begin{tabular}{|c|c|c|c|}
\hline Variable & Definition & Source 2002 data & Source 1999 data \\
\hline BUDGET & $\begin{array}{l}\text { Total budget for banking supervision } \\
\text { (in USD) }\end{array}$ & WB 2003 & WB 1999 \\
\hline STAFF & $\begin{array}{l}\text { Total number of professional bank } \\
\text { supervisors }\end{array}$ & WB 2003 & WB 1999 \\
\hline ASSETS & Total bank assets (in USD) & $\begin{array}{l}\text { WB 2003, ECB } \\
(2002)^{1}\end{array}$ & OCC, ECB (2002) ${ }^{1}$ \\
\hline DEPOSITS & Total bank deposits (in USD) & $\begin{array}{l}\text { WB 2003, ECB } \\
(2002)^{1}\end{array}$ & OCC, ECB $(2002)^{1}$ \\
\hline CLAIMS & Bank claims on private sector (in USD) & IFS (line 22d) & IFS (line 22d) \\
\hline BANKS & Number of banks & WB 2003 & $\begin{array}{l}\text { OCC, Barth et al. } \\
\text { (2002) }\end{array}$ \\
\hline HOMOGEN & $\begin{array}{l}\text { Variable indicating how homogeneous } \\
\text { the banking market is. This variable is } \\
\text { constructed by summing up the squared } \\
\text { percentage of banking system's assets } \\
\text { in banks that are } 50 \% \text { or more } \\
\text { government owned, foreign owned, and } \\
\text { privately domestic owned, respectively. } \\
\text { By definition this variable ranges from } \\
0.33 \text { to } 1 \text {; } 1 \text { indicating the highest } \\
\text { degree of homogeneity. }\end{array}$ & $\begin{array}{l}\text { Authors (percentage } \\
\text { of assets that are } \\
\text { government and } \\
\text { foreign owned: WB } \\
\text { 2003) }\end{array}$ & $\begin{array}{l}\text { Authors (percentage } \\
\text { of assets that are } \\
\text { government and } \\
\text { foreign owned: WB } \\
\text { 1999) }\end{array}$ \\
\hline CONCA & $\begin{array}{l}\text { Fraction of assets held by the } 5 \text { (for } \\
2002 \text { data)/3 (for } 1999 \text { data) largest } \\
\text { banks (in percent) }\end{array}$ & WB 2003 & OCC \\
\hline CONCD & $\begin{array}{l}\text { Fraction of deposits held by the } 5 \text { (for } \\
2002 \text { data)/3 (for } 1999 \text { data) largest } \\
\text { banks (in percent) }\end{array}$ & WB 2003 & OCC \\
\hline DRATES & $\begin{array}{l}\text { Lending minus deposit rate ( } 5 \text { year } \\
\text { average) }\end{array}$ & $\begin{array}{l}\text { IFS (lines } 601 \text { and } \\
60 \mathrm{p})\end{array}$ & $\begin{array}{l}\text { IFS (lines } 601 \text { and } \\
60 \mathrm{p} \text { ) }\end{array}$ \\
\hline NPL & Non-performing loans ratio (in percent) & WB 2003 & OCC \\
\hline MULTI & $\begin{array}{l}\text { Dummy variable indicating whether } \\
\text { there are multiple bank supervisory } \\
\text { authorities (1:more than one bank } \\
\text { supervisor) }\end{array}$ & WB 2003 & Barth et al. (2002) \\
\hline CB & $\begin{array}{l}\text { Dummy variable indicating whether the } \\
\text { central bank is involved in bank } \\
\text { supervision (1:central bank is involved) }\end{array}$ & WB 2003 & Barth et al. (2002) \\
\hline DI & $\begin{array}{l}\text { Dummy variable indicating whether } \\
\text { there is explicit deposit insurance } \\
\text { (1:explicit deposit insurance) }\end{array}$ & WB 2003 & $\begin{array}{l}\text { World Bank deposit } \\
\text { insurance database }\end{array}$ \\
\hline GDPCAP & $\begin{array}{l}\text { GDP per capita ( } 5 \text { year average; } \\
\text { constant } 1995 \text { USD) }\end{array}$ & WDI & WDI \\
\hline
\end{tabular}




\section{Table A1: continued}

OECD

EU15

EWU

EU25
OECD dummy (1:OECD member)

Authors

Authors

Authors

Authors
Authors

Authors

Authors

Authors

Note: WB 2003: 2003 World Bank survey of Bank Regulation and Supervision, WB 1999: 1999 World Bank survey of Bank Regulation and Supervision, a detailed description of this data as well as download:

http://www.worldbank.org/research/projects/bank_regulation.htm; OCC: Survey of the U.S. Office of the Comptroller of the Currency; IFS: IMF’s International Financial Statistics; WDI: World Bank’s World Development Indicators

${ }^{1}$ For the countries Austria, France, and Ireland data from ECB (2002)

${ }^{2}$ A detailed description of this data as well as download

http://www.worldbank.org/research/interest/confs/upcoming/deposit_insurance/data.htm 
Table A2: Descriptive statistics

\begin{tabular}{lrrrrrr}
\hline Variable & \multicolumn{1}{c}{ Mean } & \multicolumn{1}{c}{ Median } & \multicolumn{1}{c}{ Max. } & \multicolumn{1}{c}{ Min. } & Std. Dev. & Obs. \\
\hline BUDGET & $24,147,520$ & $5,168,460$ & $949,000,000$ & 6,964 & $95,754,176$ & 118 \\
STAFF & 143 & 52 & 2587 & 2 & 265 & 183 \\
ASSETS & $439 \mathrm{bn}$. & $18.4 \mathrm{bn}$. & $7,210 \mathrm{bn}$. & 323,766 & $1,270 \mathrm{bn}$. & 188 \\
DEPOSITS & $267 \mathrm{bn}$. & $12.6 \mathrm{bn}$. & $5,780 \mathrm{bn}$. & 126,691 & $868 \mathrm{bn}$. & 188 \\
CLAIMS & $189 \mathrm{bn}$. & $6.93 \mathrm{bn}$. & $5,080 \mathrm{bn}$. & $1,000,000$ & $697 \mathrm{bn}$. & 222 \\
BANKS & 180 & 23 & 8,580 & 1 & 883 & 197 \\
HOMOGEN & 0.62 & 0.58 & 1.00 & 0.33 & 0.19 & 195 \\
CONCA & 64.69 & 64.80 & 100.00 & 14.00 & 22.06 & 179 \\
CONCD & 66.86 & 69.00 & 100.00 & 0.02 & 22.11 & 179 \\
DRATES & 8.76 & 6.40 & 55.54 & 0.18 & 8.53 & 198 \\
NPL & 8.19 & 6.30 & 38.52 & 0.05 & 8.25 & 172 \\
MULTI & 0.14 & 0 & 1 & 0 & 0.35 & 197 \\
CB & 0.71 & 1 & 1 & 0 & 0.46 & 194 \\
DI & 0.59 & 1 & 1 & 0 & 0.49 & 190 \\
GDPCAPITA & $8,780.48$ & $3,028.36$ & $52,943.40$ & 142.68 & $11,640.18$ & 226 \\
OECD & 0.26 & 0 & 1 & 0 & 0.44 & 226 \\
EU & 0.13 & 0 & 1 & 0 & 0.34 & 226 \\
EWU & 0.11 & 0 & 1 & 0 & 0.31 & 226 \\
EU25 & 0.22 & 0 & 1 & 0 & 0.42 & 226 \\
\hline & & & & &
\end{tabular}




\section{Table A3: Countries included}

\begin{tabular}{lll}
\hline EU 15 countries & OECD countries & Others \\
\hline Austria, Belgium, Denmark, & Australia, Canada, Czech & Albania, Argentina, Armenia, \\
France, Finland, Germany, & Republic, Hungary, Iceland, & Azerbaijan, Bahrain, Belarus, \\
Greece, Ireland, Italy, & Japan, Mexico, New Zealand, & Belize, Bhutan, Bolivia, Bosnia \\
Luxembourg, Netherlands, & Norway, Poland, Slovakia, & \& Herzegovina, Botswana, \\
Portugal, Spain, Sweden, United & Switzerland, Turkey, United & Brazil, Bulgaria, Burundi, \\
Kingdom, & States, & Cambodia, Chile, Colombia, \\
& Croatia, Cyprus, Ecuador, El \\
& Salvador, Estonia, Gambia, \\
& Ghana, Guatemala, Guinea, \\
& Guyana, Honduras, Hong Kong, \\
& India, Indonesia, Israel, Jamaica, \\
& Jordan, Kenya, Kuwait, \\
& Kyrgyzstan, Latvia, Lebanon, \\
& Lithuania, Macau, Macedonia, \\
& Madagascar, Malaysia, Malta, \\
& Mauritius, Moldova, Morocco, \\
& Namibia, Nepal, Nicaragua, \\
& Nigeria, Oman, Pakistan, \\
& Panama, Papua New Guinea, \\
& Paraguay, Peru, Philippines, \\
& Puerto Rico, Romania, Rwanda, \\
& Samoa (Western), Saudi Arabia, \\
& Seychelles, Singapore, Slovenia, \\
& South Africa, Sri Lanka, St. \\
& Kitts \& Nevis, Sudan, Suriname, \\
& Swaziland, Tajikistan, Thailand, \\
& Tonga, Trinidad \& Tobago, \\
& Tunisia, Turkmenistan, United \\
Arab Emirates, Uruguay, \\
Vanuatu, Venezuela, Zimbabwe \\
\hline
\end{tabular}

Note: Table displays all countries that are included in at least one regression. Not for all countries is data available for both 1999 and 2002. All EU countries are also OECD member countries. 
Table A4: EU values of the explanatory variables used in the predictions (summary statistics)

\begin{tabular}{|c|c|c|c|c|c|c|c|}
\hline \multirow[b]{2}{*}{ Variable } & \multirow[b]{2}{*}{$\begin{array}{c}\text { Value used } \\
\text { for predictions }\end{array}$} & \multicolumn{6}{|c|}{ EU 15} \\
\hline & & Sum & $\begin{array}{c}\text { Weighted } \\
\text { average }\end{array}$ & Mean & Min. & Max. & Std. Dev. \\
\hline STAFF & 3754 & 3754 & & 250 & 30 & 1220 & 308 \\
\hline ASSETS & 22050 bn. & 22050 bn. & & 1470 bn. & 102 bn. & 5715 bn. & 1794 bn \\
\hline DEPOSITS & 11458 bn. & 11458 bn. & & 764 bn. & 35 bn. & 3732 bn. & $1167 \mathrm{bn}$ \\
\hline CLAIMS & 8562 bn. & 8562 bn. & & $571 \mathrm{bn}$. & 26 bn. & 2236 bn. & 706 bn \\
\hline HOMOGEN & 0.45/0.33/0.1 & & $0.60^{1}$ & 0.71 & 0.44 & 1 & 0.22 \\
\hline CONCA & $40.69 / 20 / 10$ & & $40.69^{1}$ & 62.80 & 20.00 & 99.50 & 26.83 \\
\hline CONCD & $38.19 / 20 / 10$ & & $38.19^{2}$ & 64.75 & 21.00 & 99.70 & 27.66 \\
\hline MULTI & 0 & & & 0.13 & 0 & 1 & 0.35 \\
\hline CB & 0 & & & 0.53 & 0 & 1 & 0.52 \\
\hline DI & 1 & & & 1.00 & 1 & 1 & 0.00 \\
\hline GDPCAPITA & 20863 & & $20863^{3}$ & 27554 & 12447 & 52943 & 10225 \\
\hline
\end{tabular}

Notes: All data refers to the year 2002. ${ }^{1}$ ASSETS used as a weight; ${ }^{2}$ DEPOSITS used as a weight; ${ }^{3}$ population used as a weight. 